\title{
Bovine erythrocyte-agglutinin as a possible adhesin of Bordetella bronchiseptica responsible for binding to porcine nasal epithelium
}

\author{
H. ISHIKAWA and Y. ISAYAMA
}

Hokkaido Research Station, National Institute of Animal Health, Hitsujigaoka, Toyohira-ku, Sapporo, 004, Japan

\begin{abstract}
Summary. The bovine erythrocyte-agglutinin (BEA) of Bordetella bronchiseptica, located on the cell surface in non-fimbrial form, has been identified as a possible adhesin responsible for binding to porcine nasal epithelium in studies with BEAnegative $\left(\mathrm{BEA}^{-}\right)$mutants and in competitive studies with bovine erythrocytes.
\end{abstract}

\section{Introduction}

The ability of bacteria to attach to mucosal surfaces has been recognised as an important determinant influencing the successful colonisation of the host tissue (Jones and Rutter, 1972; Fader and Davis, 1980; Beachey, 1981). Many gramnegative bacteria possess surface structures which may serve as adhesins and are often associated with the ability of the organisms to cause haemagglutination. Bacterial haemagglutination correlates well with the adherence of the organisms to host cells (Punsalang and Sawyer, 1973; Koransky et al., 1975; Burrows et al., 1976; Finkelstein and Hanne, 1982; Svenson et al., 1983; Goldhar et al., 1984; Pruzzo et al., 1984), and thus has been widely used as a model of host-parasite surface interactions (Svenson et al., 1983; Korhonen et al., 1984). Virulent bacteria tend to be more adhesive (Jones and Rutter, 1972; Punsalang and Sawyer, 1973; van den Bosch et al., 1980) and haemagglutinating activity has been used often as a marker for identifying pathogenic isolates (Burrows et al., 1976).

Bordetella bronchiseptica, an important cause of respiratory tract disease and a frequent cause of atrophic rhinitis in swine, experiences phase variation (from phase I to rough phase) (Nakase, 1957b; Ishikawa and Isayama, 1986), and phase-I cells grown at low temperature undergo a phenotypic alteration termed antigenic modulation (from $\mathbf{X}$ to C mode) (Nakase, 1957b; Ishikawa and Isayama, 1987b). Phase variants and C-mode cells are

Received 20 Aug. 1987; accepted 20 Nov. 1987. characterised by loss or attenuation of capsular antigen (Nakase, 1957a and b; Éliás et al., 1982; Ishikawa and Isayama, 1986, 1987b), as well as loss of virulence (Nakase, 1957c; Yokomizo and Shimizu, 1979). Other studies have demonstrated that the pathogenic organisms in $\mathrm{X}$ mode attach to the surface of porcine nasal mucosa (Yokomizo and Shimizu, 1979; Ishikawa and Isayama, 1987 $a$ and b). On the contrary, non-pathogenic organisms, either in C mode or in degraded phases (phases II, III, and rough), have been shown not to attach to the target tissue (Ishikawa and Isayama, 1987b). Accordingly, adherence is thought to be of major importance to the establishment of this infection (Yokomizo and Shimizu, 1979), though the mechanisms of the adherence are as yet by no means understood. On the other hand, phase-I cells in X mode are known to produce the substance(s) capable of agglutinating erythrocytes from several animal species (Nakase, 1957c; Bemis et al., 1977; Bemis and Plotkin, 1982; Éliás et al., 1982; Krüger and Horsch, 1982; Blom et al., 1983; Rimler and Simmons, 1983; Spasojević-Rabrenović and Lončarević, 1984; Collings and Rutter, 1985). However, little is known about the haemagglutinating activity of phase variants and C-mode cells. The relationship between haemagglutination and attachment of the parasite to an epithelial surface is, therefore, still unclear and the pathogenic significance of haemagglutinin in bordetellosis remains to be determined.

The purpose of the present study was to examine the haemagglutinating pattern of $B$. bronchiseptica strains in each phase or mode and to try to identify the adhesin responsible for their binding to porcine nasal epithelial cells. 


\section{Materials and methods}

\section{Bacterial strains}

B. bronchiseptica strains mainly used in the present study were phase-I strain A19, which was a primary isolate from a pig with atrophic rhinitis, and its substrains A19-CV200 (phase II), A19-CV300 (phase III), and A19CV400 (rough phase). Three other phase-I strains (S1, $\mathrm{H16}$, and ATCC4617) and their substrains in degraded phases were also examined. Methods for induction of phase variants as well as $\mathrm{C}$-mode cells were described in detail elsewhere (Ishikawa and Isayama, 1986, 1987b). Cultures were maintained on Bordet-Gengou agar (Difco Laboratories, Detroit, MI, USA) containing defibrinated sheep blood $7 \%$, and stored at $4^{\circ} \mathrm{C}$.

\section{Erythrocytes}

Blood was collected into Alsever's solution from man (group O), horse, cow, sheep, goat, pig, dog, rabbit, guinea-pig, and chicken. Erythrocytes were washed three times in $0.01 \mathrm{M}$ sodium phosphate-buffered saline (PBS;

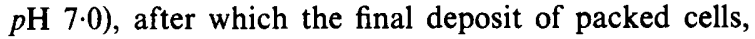
produced by centrifugation for $10 \mathrm{~min}$ at $700 \mathrm{~g}$, was suspended in PBS to $0.5 \% \mathrm{v} / \mathrm{v}$.

\section{Haemagglutination assay}

Bacteria for the assay were collected from 18 -h cultures on Bordet-Gengou agar, washed twice, and suspended in PBS to a density of $10^{10} \mathrm{cells} / \mathrm{ml}$. The assay was performed in microtitration plates with round-bottomed wells. After making two-fold serial dilutions of the bacterial suspensions, equal volumes $(25 \mu \mathrm{l})$ of erythrocytes were added. The plates were then shaken, sealed, and incubated for $2 \mathrm{~h}$ at $37^{\circ} \mathrm{C}$ before reading the results. The haemagglutination titre is the highest dilution that caused complete agglutination.

\section{Enrichment and selection of $B E A^{-}$mutants}

Spontaneous mutants that had lost the ability to produce bovine erythrocyte-agglutinin (BEA) were selected from strain A19. One colony of the strain was inoculated into $5 \mathrm{ml}$ of Trypticase Soy Broth (BBL Microbiology Systems, Cockeysville, MD, USA) and propagated overnight at $37^{\circ} \mathrm{C}$. The culture was added to $1 \mathrm{ml}$ of packed bovine erythrocytes. After shaking for $2 \mathrm{~h}$ at ambient temperature to allow the bacteria to attach to the erythrocytes, the mixture was held overnight at $4^{\circ} \mathrm{C}$. The BEA-negative $\left(\mathrm{BEA}^{-}\right)$bacteria-enriched supernate was absorbed one more time and then inoculated into fresh broth and the cycle was repeated. Portions of the enriched supernates were diluted and plated on BordetGengou agar. After incubation for 2 days at $37^{\circ} \mathrm{C}$, isolated colonies were screened with a rapid slide haemagglutination test to detect $\mathrm{BEA}^{-}$mutants. At least nine such selective passages were required to permit the isolation of $\mathrm{BEA}^{-}$mutants. Spontaneous mutants were not detected during passages without the enrichment procedure.

\section{Adherence assay}

The adherence of bacteria was examined with epithelial cells obtained from ventral turbinate mucosae of pigs as described elsewhere (Ishikawa and Isayama, 1987a and $b$ ).

\section{Competitive inhibition with bovine erythrocytes}

Competitive inhibition of bacterial adherence was tested with bovine erythrocytes. A test mixture consisted of $0.3 \mathrm{ml}$ of epithelial cells $\left(6 \times 10^{5}\right.$ cells $), 0.15 \mathrm{ml}$ of bacteria $\left(6 \times 10^{7}\right.$ cells), and $0.15 \mathrm{ml}$ of erythrocytes $(6 \times$ $10^{5}$ cells). The bacteria were pre-incubated for $30 \mathrm{~min}$ at $37^{\circ} \mathrm{C}$ with the erythrocytes. The adherence was compared with that in the control mixture lacking erythrocytes.

\section{Bacterial agglutination with capsular antiserum}

The agglutinability with capsular antiserum of bacteria in each phase or mode was determined as reported previously (Ishikawa and Isayama, 1986).

\section{Electronmicroscopy}

Bacterial suspensions in $1 \%$ ammonium acetate were negatively stained with uranyl acetate and examined for fimbriation with a Hitachi HS-9 electronmicroscope (Hitachi, Tokyo, Japan).

\section{Results}

\section{Haemagglutinating activity}

Initial studies were done to screen the bacteria in each phase or mode for their ability to agglutinate erythrocytes of various species. The characteristic patterns of haemagglutination are summarised in table I. Haemagglutinating activity tended to be strong among phase-I cells in $X$ mode and to decrease on transition from $\mathrm{X}$ mode to $\mathrm{C}$ mode or from phase I to degraded phases, with the exception of the strong agglutination of human group 0 erythrocytes with variant cells in phases II, III, and rough. X-mode organisms agglutinated the erythrocytes of most species, e.g., bovine cells strongly, horse, pig, dog, rabbit, and guinea-pig cells moderately strongly, and human group 0 , sheep, and chicken cells weakly, but goat cells not at all. Identical patterns of haemagglutination were obtained when three other strains ( $\mathrm{S} 1, \mathrm{H} 16$, and ATCC4617) and their variants were examined. 
Table I. Haemagglutinating activity of $B$. bronchiseptica $\mathrm{A} 19$ and its $\mathrm{BEA}^{-}$mutants

\begin{tabular}{|c|c|c|c|c|c|c|c|}
\hline \multirow{3}{*}{$\begin{array}{l}\text { Erythrocyte } \\
\text { species }\end{array}$} & \multicolumn{7}{|c|}{ Haemagglutination titre* of strain } \\
\hline & \multicolumn{5}{|c|}{ A19 in phase (mode) } & \multirow{2}{*}{$\begin{array}{c}\text { A19- } \\
712 \text { NH }\end{array}$} & \multirow{2}{*}{$\begin{array}{l}\text { A19- } \\
718 \mathrm{NH}\end{array}$} \\
\hline & $\mathrm{I}(\mathrm{X})$ & $\mathrm{I}(\mathrm{C})$ & II & III & Rough & & \\
\hline Human group $\mathrm{O}$ & 4 & 8 & 256 & 256 & 256 & 4 & 4 \\
\hline Horse & 8 & $<2$ & $<2$ & $<2$ & $<2$ & 8 & 8 \\
\hline Bovine & 128 & 2 & 2 & $<2$ & $<2$ & $<2$ & $<2$ \\
\hline Sheep & 2 & $<2$ & $<2$ & $<2$ & $<2$ & 2 & 2 \\
\hline Goat & $<2$ & $<2$ & $<2$ & $<2$ & $<2$ & $<2$ & $<2$ \\
\hline Pig & 16 & 4 & 4 & $<2$ & $<2$ & 16 & 16 \\
\hline Dog & 16 & 4 & 4 & $<2$ & $<2$ & 16 & 16 \\
\hline Rabbit & 16 & 16 & 16 & 16 & 16 & 16 & 16 \\
\hline Guinea-pig & 8 & $<2$ & $<2$ & $<2$ & $<2$ & 8 & 8 \\
\hline Chicken & 4 & $<2$ & $<2$ & $<2$ & $<2$ & 4 & 4 \\
\hline
\end{tabular}

* Highest dilution of bacterial suspension $\left(10^{10} \mathrm{cells} / \mathrm{ml}\right)$ giving complete haemagglutination.

Thus, correlation was found between the known adhesiveness of the microbes for porcine nasal epithelium and their haemagglutinating activity with bovine erythrocytes.

It was thought that the isogenic mutants of phase1 strains which were BEA-defective would be a useful tool for attachment studies. According to the protocol described above, two $\mathrm{BEA}^{-}$mutants of strain A19, designated A19-712NH and A19$718 \mathrm{NH}$, were obtained.

The haemagglutination spectra of these mutants were examined. They failed to agglutinate bovine erythrocytes, whilst their behaviour with the erythrocytes of other species remained unchanged (table I).

\section{Adhesiveness}

The ability of $\mathrm{BEA}^{-}$mutants to attach to porcine nasal epithelial cells was compared with that of their parent strain (table II). The phase-I parent in $\mathrm{X}$ mode adhered well to the epithelial cells, whereas the mutants showed feeble adherence to the same cells, as did the cells in C mode or in degraded phases.

\section{Competitive inhibition with bovine erythrocytes}

To confirm the involvement of BEA in epithelial cell adherence, X-mode cells were pre-incubated with bovine erythrocytes (table III). The erythro-

Table II. K-agglutinability and adhesiveness of $B$. bronchiseptica A19 and its $\mathrm{BEA}^{-}$mutants

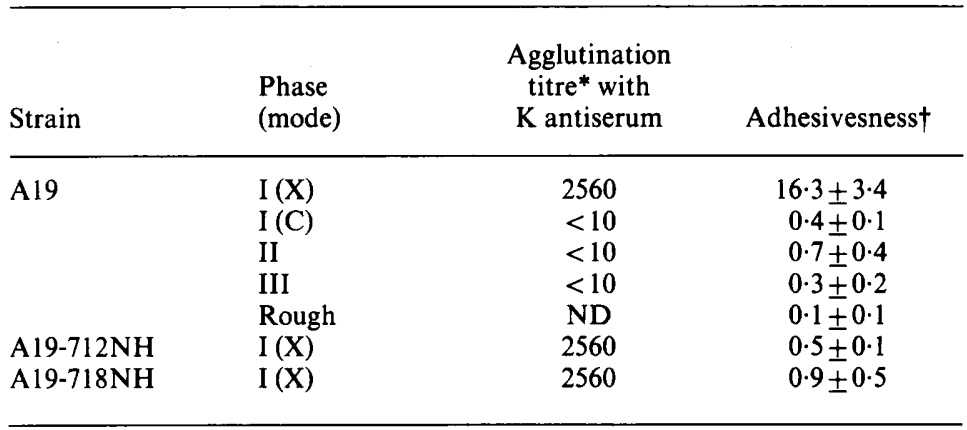

ND = not determined, because of spontaneous agglutination in PBS.

* Highest dilution of antiserum giving complete agglutination.

$\dagger$ Mean number of bacteria attached per epithelial cell \pm SD was determined from triplicate assays. 
Table III. Effect of pre-incubation of $B$. bronchiseptica A19 X-mode cells with bovine erythrocytes on their adherence to porcine nasal epithelial cells

\begin{tabular}{lc}
\hline Pre-incubation & $\begin{array}{c}\text { Adherence* } \\
\text { (percentage } \\
\text { reduction) }\end{array}$ \\
\hline None & $12 \cdot 4 \pm 1.0$ \\
Bovine erythrocytes & $1.9 \pm 0.4(85)$ \\
\hline
\end{tabular}

* Mean number of bacteria attached per epithelial cell \pm SD was determined from triplicate assays.

cytes prevented adhesion of all strains examined. This may suggest that the erythrocytes inhibit adhesion by competing with the epithelial cells for the specific binding sites on the bacterial surface.

\section{Capsulation and fimbriation}

$\mathrm{BEA}^{-}$mutants, as well as their parent, possessed capsules and were agglutinated by capsular antiserum (table II). No fimbriation was observed when they were examined by electronmicroscopy.

\section{Discussion}

Muitiple types of haemagglutinins are likely to be expressed by $B$. bronchiseptica, and at least two types are thought to exist on the surface of $\mathrm{X}$-mode organisms since mutants deficient in the production of BEA agglutinate the erythrocytes of other species.

\section{REFERENCES}

Beachey E H 1981 Bacterial adherence: adhesin-receptor interactions mediating the attachment of bacteria to mucosal surfaces. Journal of Infectious Diseases 143:325345 .

Bemis D A, Greisen H A, Appel M J G 1977 Bacteriological variation among Bordetella bronchiseptica isolates from dogs and other species. Journal of Clinical Microbiology 5:471480.

Bemis D A, Plotkin B J 1982 Hemagglutination by Bordetella bronchiseptica. Journal of Clinical Microbiology 15:11201127.

Bemis D A, Wilson S A 1985 Influence of potential virulence determinants on Bordetella bronchiseptica-induced ciliostasis. Infection and Immunity 50:35-42.

Blom J, Hansen G A, Poulsen F M 1983 Morphology of cells and hemagglutinogens of Bordetella species: resolution of substructural units in fimbriae of Bordetella pertussis. Infection and Immunity 42:308-317.

Burrows M R, Sellwood R, Gibbons R A 1976 Haemagglutinating and adhesive properties associated with the $\mathrm{K} 99$
A correlation was found between the lack of haemagglutinating activity for bovine erythrocytes and a concomitant decrease in adherence to porcine nasal epithelial cells. The organisms that could agglutinate bovine erythrocytes were strongly adherent to porcine nasal epithelial cells, whereas organisms that did not agglutinate the erythrocytes exhibited only negligible adherence. The result of the competitive inhibition tests indicated the possible involvement of BEA in the epithelial-cell adherence. Although BEA thus seems to be important in adherence, other cell-surface structures such as capsules and fimbriae, do not seem to be critical for adherence. The ability of the bacteria to adhere correlated neither with capsulation nor with fimbriation. Mutants lacking BEA still reacted with capsular antiserum. Thus, if BEA is a constituent of capsules, it is not the major epitope recognised by antibodies in the capsular antiserum. On the other hand, both the mutants and the parent were devoid of any detectable fimbriae, though the possession of fimbriae by this species has been reported (Bemis et al., 1977; Bemis and Plotkin, 1982; Blom et al., 1983; Bemis and Wilson, 1985; Collings and Rutter, 1985; Kielstein and Reckling, 1985; Lee et al., 1986). Our results indicate that BEA is of a non-fimbrial nature and probably functions as an adhesin that mediates the attachment of $B$. bronchiseptica to porcine nasal epithelial cells. These findings may be of some value for further elucidation of the adhesion mechanisms of $B$. bronchiseptica with BEA as a likely marker for isolates of this species that have the capability to adhere to the organism's target cells on porcine nasal epithelium.

antigen of bovine strains of Escherichia coli. Journal of General Microbiology 96:269-275.

Collings L A, Rutter J M 1985 Virulence of Bordetella bronchiseptica in the porcine respiratory tract. Journal of Medical Microbiology 19:247-255.

Éliás B, Krüger M, Rátz F 1982 Epizootiologische Untersuchungen der Rhinitis atrophicans des Schweines. II. Biologische Eigenschaften der von Schweinen isolierten Bordetella bronchiseptica-Stämme. Zentralblatt für Veterinärmedizin $B$ 29:619-635.

Fader R C, Davis C P 1980 Effect of piliation on Klebsiella pneumoniae infection in rat bladders. Infection and Immunity 30:554-561.

Finkelstein R A, Hanne L F 1982 Purification and characterization of the soluble hemagglutinin (cholera lectin) produced by Vibrio cholerae. Infection and Immunity 36:11991208.

Goldhar J, Perry R, Ofek I 1984 Extraction and properties of nonfimbrial mannose-resistant hemagglutinin from a urinary isolate of Escherichia $\cdot$ coli. Current Microbiology 11:49 54.

Ishikawa H, Isayama Y 1986 Bordetella bronchiseptica phase 
variation induced by crystal violet. Journal of Clinical Microbiology 23: 235-239.

Ishikawa $\mathrm{H}$, Isayama Y $1987 a$ Evidence for sialyl glycoconjugates as receptors for Bordetella bronchiseptica on swine nasal mucosa. Infection and Immunity 55:1607-1609.

Ishikawa H, Isayama Y $1987 b$ Effect of antigenic modulation and phase variation on adherence of Bordetella bronchiseptica to porcine nasal epithelial cells. American Journal of Veterinary Research 48: 1689-1691.

Jones G W, Rutter J M 1972 Role of the K88 antigen in the pathogenesis of neonatal diarrhea caused by Escherichia coli in piglets. Infection and Immunity 6:918-927.

Kielstein P, Reckling K F 1985 Untersuchungen zu Zusammenhängen zwischen Wachstumseigenschaften und Virulenzfaktoren von Bordetella bronchiseptica. Archiv für experimentelle Veterinärmedizin 39:429-440.

Koransky J R, Scales R W, Kraus S J 1975 Bacterial hemagglutination by Neisseria gonorrhoeae. Infection and Immunity 12: 495-498.

Korhonen T K, Väisänen-Rhen V, Rhen M, Pere A, Parkkinen J, Finne J 1984 Escherichia coli fimbriae recognizing sialyl galactosides. Journal of Bacteriology 159:762-766.

Krüger M, Horsch F 1982 Untersuchungen zur Differenzierung von Bordetella-bronchiseptica-Stämmen. 1. Mitteilung: Nachweis des hitzelabilen Exotoxins und des Hämagglutinins. Archiv für experimentelle Veterinärmedizin 36:691-698.

Lee S W, Way A W, Osen E G 1986 Purification and subunit heterogeneity of pili of Bordetella bronchiseptica. Infection and Immunity 51 : 586-593.

Nakase Y 1957 a Studies on Haemophilus bronchisepticus. I. The antigenic structures of $H$. bronchisepticus from guinea pig. Kitasato Archives of Experimental Medicine 30:57-72.
Nakase Y $1957 b$ Studies on Haemophilus bronchisepticus. II. Phase variation of $H$. bronchisepticus. Kitasato Archives of Experimental Medicine 30:73-78.

Nakase Y 1957c Studies on Haemophilus bronchisepticus. III. Differences of biological properties between phase I and phase III of $H$. bronchisepticus. Kitasato Archives of Experimental Medicine 30: 79-84.

Pruzzo C, Dainelli B, Ricchetti M 1984 Piliated Bacteroides fragilis strains adhere to epithelial cells and are more sensitive to phagocytosis by human neutrophils than nonpiliated strains. Infection and Immunity 43:189-194.

Punsalang A P Jr, Sawyer W D 1973 Role of pili in the virulence of Neisseria gonorrhoeae. Infection and Immunity 8:255-263.

Rimler R B, Simmons D G 1983 Differentiation among bacteria isolated from turkeys with coryza (rhinotracheitis). Avian Diseases 27:491-500.

Spasojević-Rabrenović V, Lončarević A 1984 Haemagglutinating activity in some Bordetella bronchiseptica strains isolated from pigs with acute rhinitis. Acta Veterinaria, Beograd 34: 189-197.

Svenson S B, Hultberg H, Källenius G, Korhonen T K, Möllby R, Winberg J 1983 P-fimbriae of pyelonephritogenic Escherichia coli: identification and chemical characterization of receptors. Infection 11:61-67.

Van den Bosch J F, Verboom-Sohmer U, Postma P, de Graaff J, MacLaren D M 1980 Mannose-sensitive and mannoseresistant adherence to human uroepithelial cells and urinary virulence of Escherichia coli. Infection and Immunity 29:226233.

Yokomizo Y, Shimizu T 1979 Adherence of Bordetella bronchiseptica to swine nasal epithelial cells and its possible role in virulence. Research in Veterinary Science 27:15-21. 